\title{
Why Alice is not in Wonderland? Countering the Militarized status quo of Cyprus
}

\author{
Socrates Stratis \\ University of Cyprus, Department of Architecture \\ stratiss@ucy.ac.cy
}

\begin{abstract}
Why Alice is not in Wonderland? Countering the militarized status quo of Cyprus is a narrative, part of the author's diary. It is a reflection on a critical spatial practice, a performative event, titled "Alice in Meridianland... or the counter-militarization action", part of the Buffer Fringe Performance Festival, Nicosia, Cyprus, 2019. The critical spatial practice comments on Cyprus' actual militarization status by offering alternative urban imaginaries for the urban commons of an island without armies. It has taken place along a loop of streets and public spaces both in the north and the south parts of divided Nicosia. "Alice in Meridianland" is a camouflage tactic to conceal its anti-militaristic nature while crossing the guarded checkpoints into the city's north part. Two tricycles, pulling 3-meter-long banners, have followed the loop in opposite directions, three times. They met at designated areas and formed instant spaces of playful interaction. The narrative unpacks the entanglements between the performative event and the city's users of the streets and public spaces. It unfolds how the event has generated new associations between the public spaces and the feelings of the participants and of the author. How it readjusted their mental maps and urban imaginaries. The narrative is a reflective tool for critical spatial practices in producing situated knowledge.
\end{abstract}

Keywords: critical spatial practice, counter-militarization, narrative, mental maps, urban commons

To cite this article:

Stratis, S. (2020) Why Alice is not in Wonderland? Countering the Militarized status quo of Cyprus, The Journal of Public Space, 5(4), 193-208, DOI I0.3289I/jps.v5i4.I 405

This article has been reviewed by the Editors and accepted for publication in The Journal of Public Space.

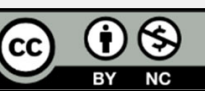

This work is licensed under a Creative Commons Attribution - Non Commercial 4.0

International License https://creativecommons.org/licenses/by-nc/4.0/ 
Why Alice is not in Wonderland? Countering the Militarized status quo of Cyprus

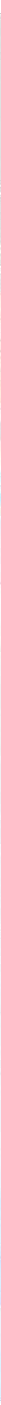

"Why?" a six-year-old Syrian boy is asking me. He is standing by the two tricycles that pull the three-meter-long banners-on-wheels with "Alice...in Meridianland"'. He is following us along Ledra street, all the way from Eleftheria square, located at the south edge of the old city of Nicosia. He is on foot and his buddy on a tiny bike. "Why can't I come with you?" He is persistent. We are situated in the old city center, next to the Republic of Cyprus checkpoint. We are heading to Ataturk square, the historical central square of Nicosia. It is five minutes bike ride away from where we are standing. We are forming a procession. One biker at the front, one tricycle following, and a biker at the end. Just a few minutes before, we occupied the newly designed Eleftheria square. It is the main square of the south part of Nicosia, a bridge connecting the new with the old city, designed by Zaha Hadid. It is very much contested by the city's inhabitants and wellguarded by private security. We formed space between the two banners-on-wheels and placed blue color cushions on the floor, reclaiming the square. Two o'clock in the afternoon on October 26th and it is still unbearably hot in the shadowless public space.

\footnotetext{
' Project Team: Laboratory of Urbanism University of Cyprus (LUCY) and AA \& U for Architecture, Art and Urbanism (project leader: S. Stratis). http://www.aaplusu.com/en/projects/alice-in-meridianland-orthe-counter-militarization-action-2019/57
} 

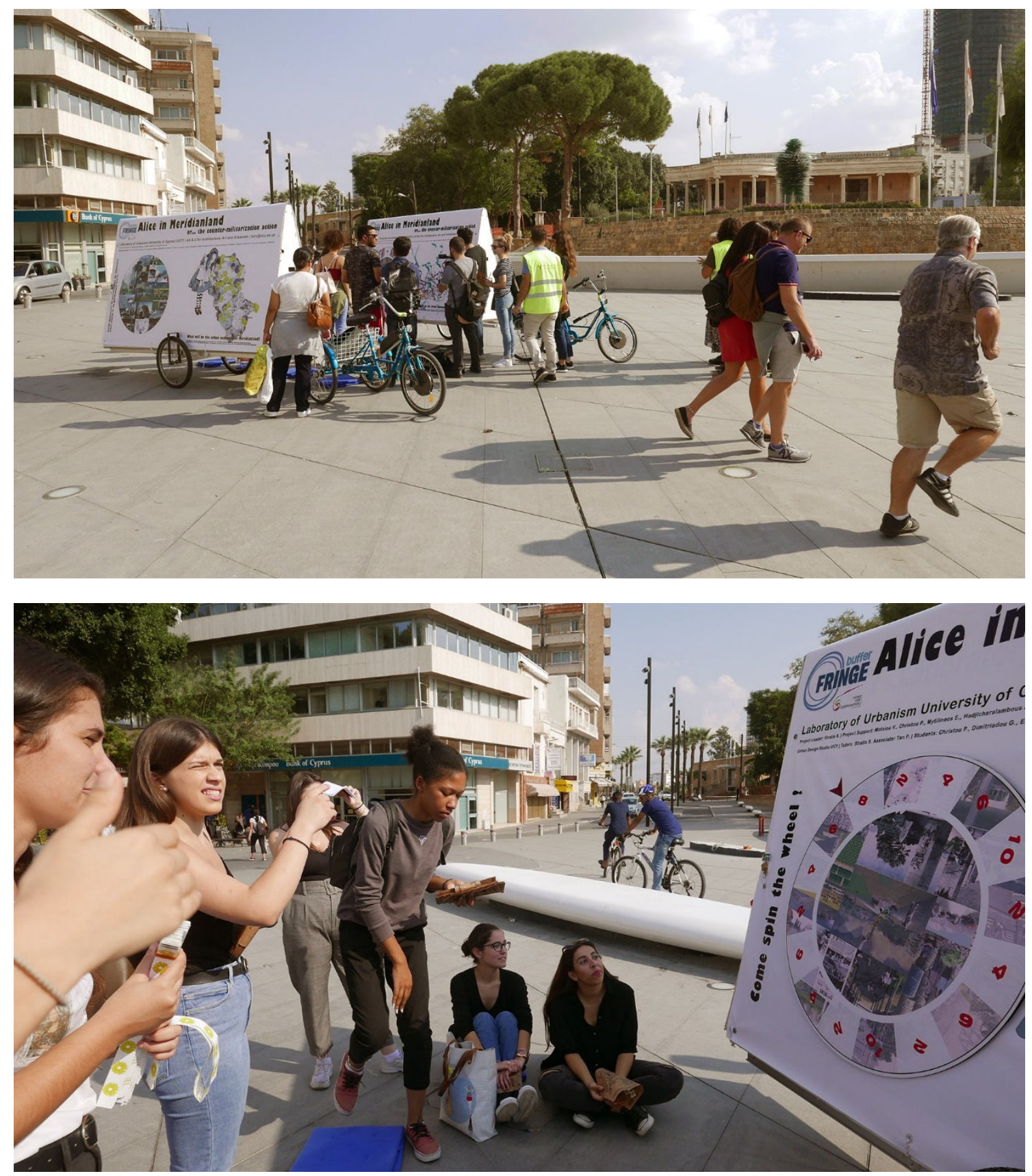

Figures I and 2. Alice in Meridianland, at Eleftheria Square, 2019. Photo AA\&U (critical spatial practice agency AA \& U for Architecture, Art, and Urbanism).

A spinning wheel is on one of the two banners facing each other. It is Alice's spinning wheel with numbers from two to ten. It is a sort of dice to help the players move along the path of a ladders \& snakes game printed on the same banner. The winner is the player who does not arrive first to No 100, but the player who collects the biggest amount of daisies' stickers along the way. There are twenty-six spots along the game board path, which correspond to a reciprocal number of boxes depicted on the second banner-on-wheels, located a few meters away. "You spin the wheel and you wait until it 
stops...", Well, our newly constructed wheel is frictionless....We forgot to put a deceleration device.

The camouflage project, that of "Alice in...Meridianland" has gotten life on its own. It is lovely to see how the kids have become unexpectedly our biggest fans during our performance. They just love watching the wheel spinning, not caring when it stops. Unlikely to their parents who are getting utterly impatient. Yet, they cannot leave. The Alice's spinning wheel, the ladders \& snakes game in combination with the sticky daisies have become the agents for the undeniable popularity of our project. Grown-ups would stay in a distance observing their kids playing. They help them sticking their daisies' trophies on the right spot of the brown color leaflet handed out to them by the volunteers. I hope they will read the information on the leaflet when they return home. The kids would keep asking for more sticky daisies. They would spin the wheel once more while their parents are begging them for their departure.

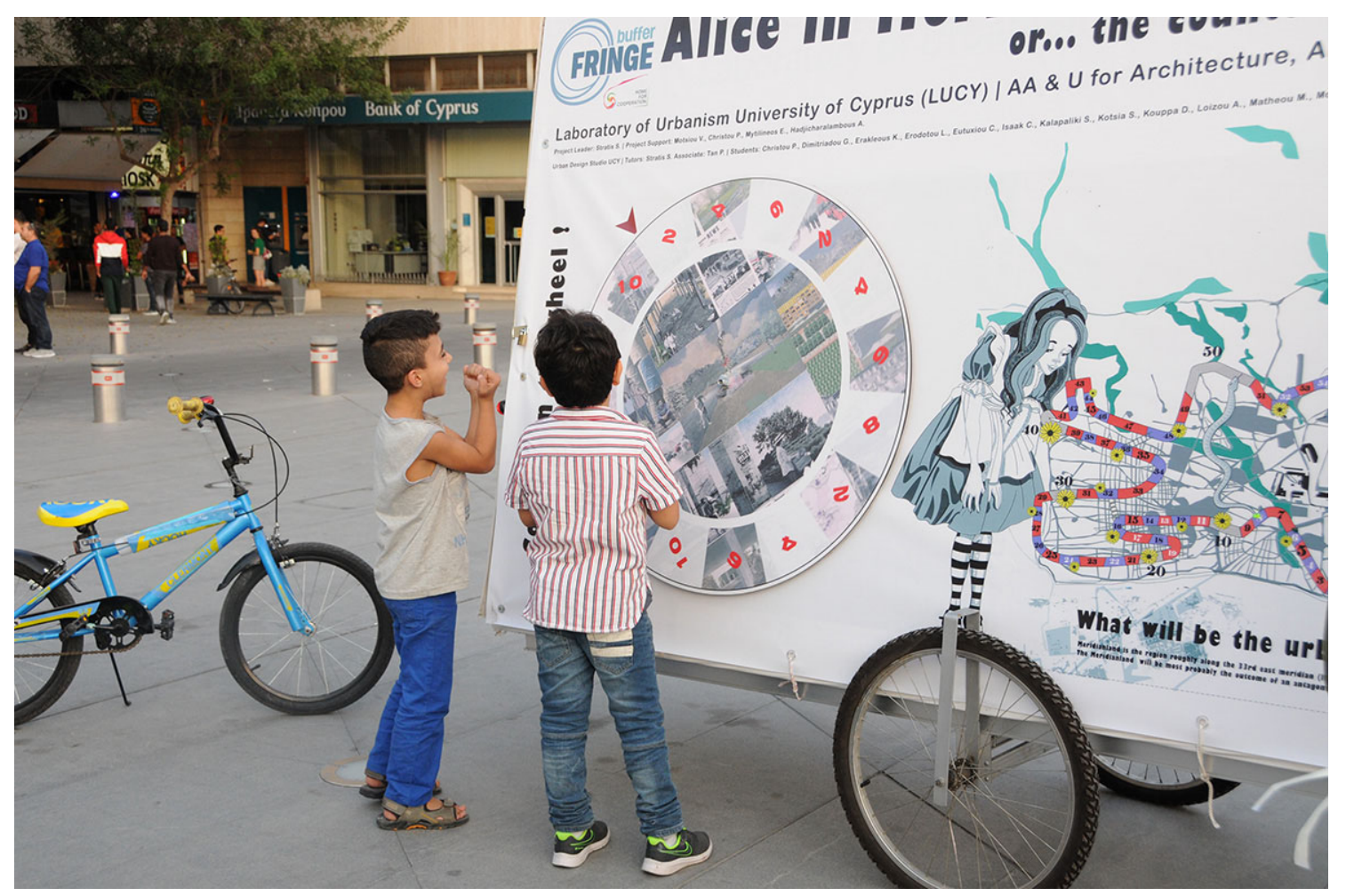

Figure 3. Alice in Meridianland, at Eleftheria Square, 2019. Photo AA\&U.

"6!!!” The wheel stopped at number six", exclaims a seven-year-old young girl. "There is a daisy at number six!". She is collecting a sticker with a yellow daisy's image printed on it. She sticks it on threefold brown paper, on a circle corresponding to the box no 6 . The two Syrian boys had to make some space for her since they were playing already for fifteen minutes before her arrival. They are competing who is spinning the wheel faster.

"No 6: Costa Rica with no armies is ranked first on the Happy Planet Index". Half of the twenty-six boxes are devoted to Costa Rica. A country with no armies since 1948, after many decades of civil war. The rest of the boxes are populated with images from the University of Cyprus students' 2018 urban design projects. "A Guide to Counter- 
Militarization" was the theme of the Urban Design Studio. The students were invited to envision co-production economies. To design a network of infrastructures that support the commons of the "Meridian" city after the island's reunification under Federal Cyprus. "Meridian" city has become "Meridianland" for our "Buffer Fringe Festival" contribution. They are equally imaginary. "Meridianland" is roughly the territory that runs along the 33rd Meridian crossing the island. It starts from Kyrenia, at the north coast, crosses Nicosia, and ends at the southern coastal city of Larnaca. What if Federal Cyprus is demilitarized? Then, we will use the former military infrastructures of all armies parked on the island, as a network of territories for the Meridianland's urban commons. The students' projects focused on a couple of Turkish military camps in the north part of the island.
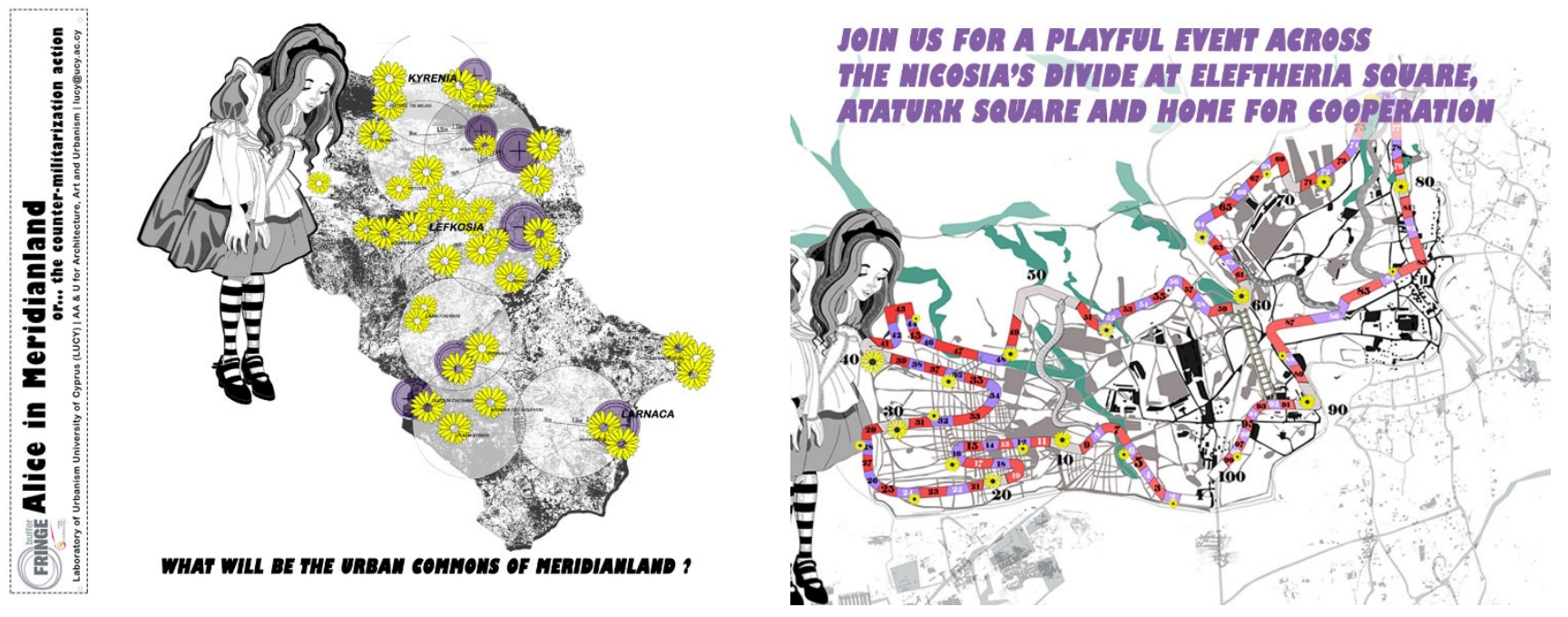

Figures 4 and 5. Alice in Meridianland, Images on the banners, 2019. Photo AA\&U.

We are patiently waiting for the policemen to make space for us to cross the checkpoint of the Republic of Cyprus into the buffer zone headed to the "TRNC" checkpoint to the north part of the city. They are polite and curious since only pedestrians cross the Ledra street checkpoint and not tricycles with banners-on-wheels. The Syrian boy continues to ask to continue the promenade with us. An oversized image of Alice is printed on the banner is overlooking both the Syrian boy and the printed map of Meridianland, full of images of yellow daisies. I almost cry when I tell him that he cannot cross the checkpoint with us. Impossible to explain to him the reasons. His question and my impossible explanation condense the heart of the Cyprus conflict. "Have you thought of the safety of the participants when you are in the north part of Nicosia?" the curator of the Buffer Fringe Performing Arts Festival, asks me. "Well, not really", is my answer. My will to change our split imaginaries as regards the isolated parts of Nicosia, cut by the UN buffer zone, has overshadowed the ground reality and any issues of safety. The reality is that Nicosia is about two cities, lying next to each other, with minimum contact between their inhabitants. "You know", she continues, "the headquarters of "Grey Wolves", the fascist Turkish political party are located by Ataturk square. They are hostile to your messages". 
"Why Alice is not in Wonderland?" is a question posed by one of the Eleftheria square's users. "Alice in Meridianland... or the counter-militarization action" is the camouflaged project's title. It is written in big bold head letters on both sides of the two banners-onwheels, at the top. Alice's oversize image printed on the banners and the spinning wheel devoted to her are all also camouflage tactics to cross the "TRNC" checkpoints to the north part of the city. To keep away any unfriendly to our message, people.

"What is the project about?" another passer-by is asking us. "It is about peace in Cyprus" is the easy answer addressed to the people along our trajectory. "It is like Alice in Wonderland... it is a game, part of the Buffer Fringe Festival" is the carefully stated answer to the Turkish Cypriot policeman at the checkpoint. He has already received the approval for our crossing from the "TRNC" Ministry of Foreign Affairs thanks to the Festival's organizers. Each time, we cross the checkpoint at Ledra street, a "TRNC" policeman takes a picture of the images on the banners, with his smartphone. Will he identify the site plan of the enormous artillery camp, next to Kythrea printed on the banner? A camp, three times the size of the walled city of Nicosia. The artillery exercise trails marked on the ground, are covered with the images of the game's snakes and ladders.

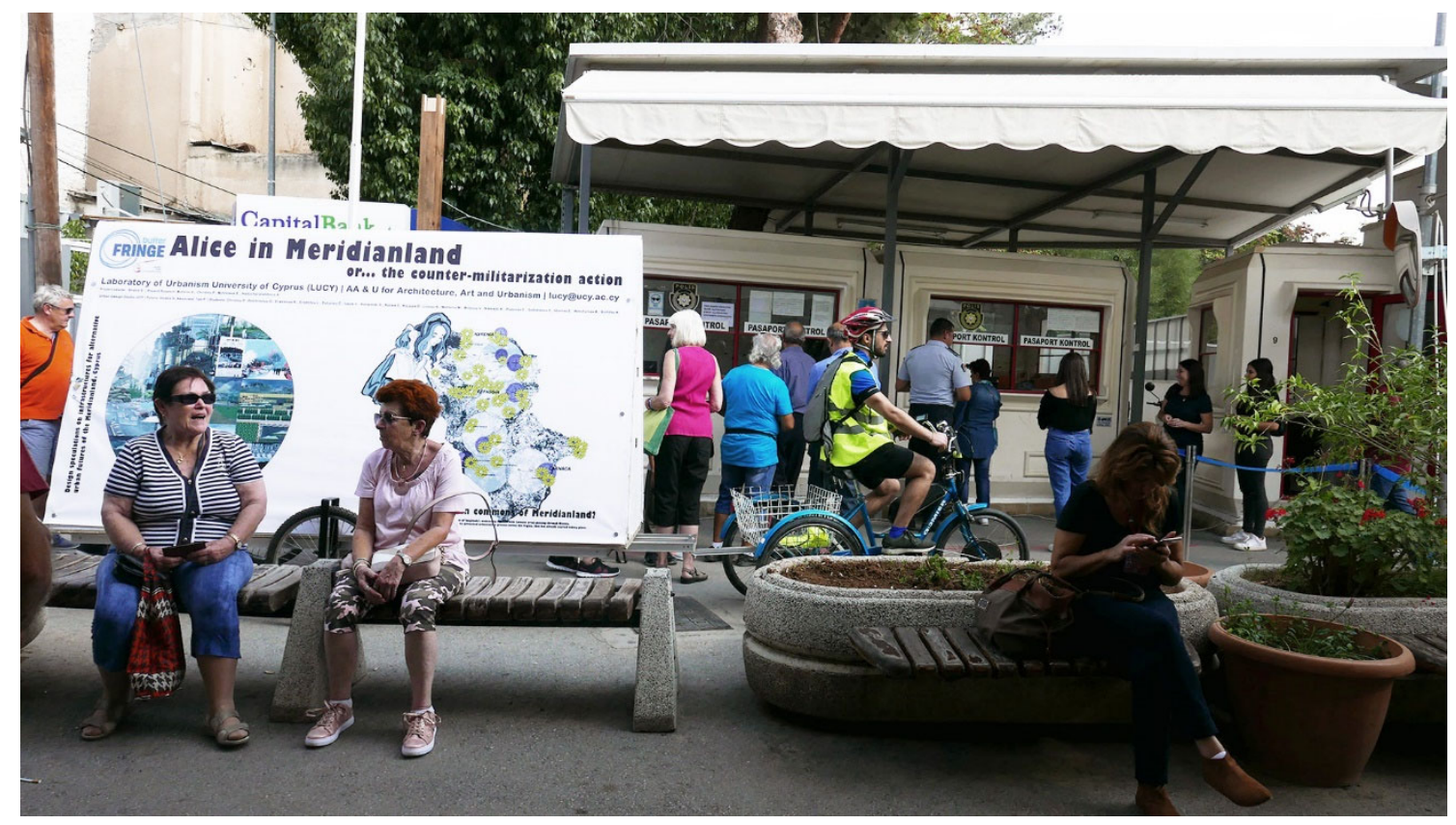

Figure 6. Alice in Meridianland, crossing the check point from the north to the south part of Nicosia, 2019. Photo AA\&U.

Our action is a symbolic canceling of the UN buffer zone, criticizing its use as the only meeting place for Turkish Cypriots and Greek Cypriots. Each of the two tricycles pulling the banners with a leading bike forms a loop procession that traverses the divide across two checkpoints. The two-loop processions run simultaneously in a clockwise and an anticlockwise direction. They are scheduled to meet in the Buffer Fringe Festival grounds as well as at the two major squares of the south and north Nicosia. 


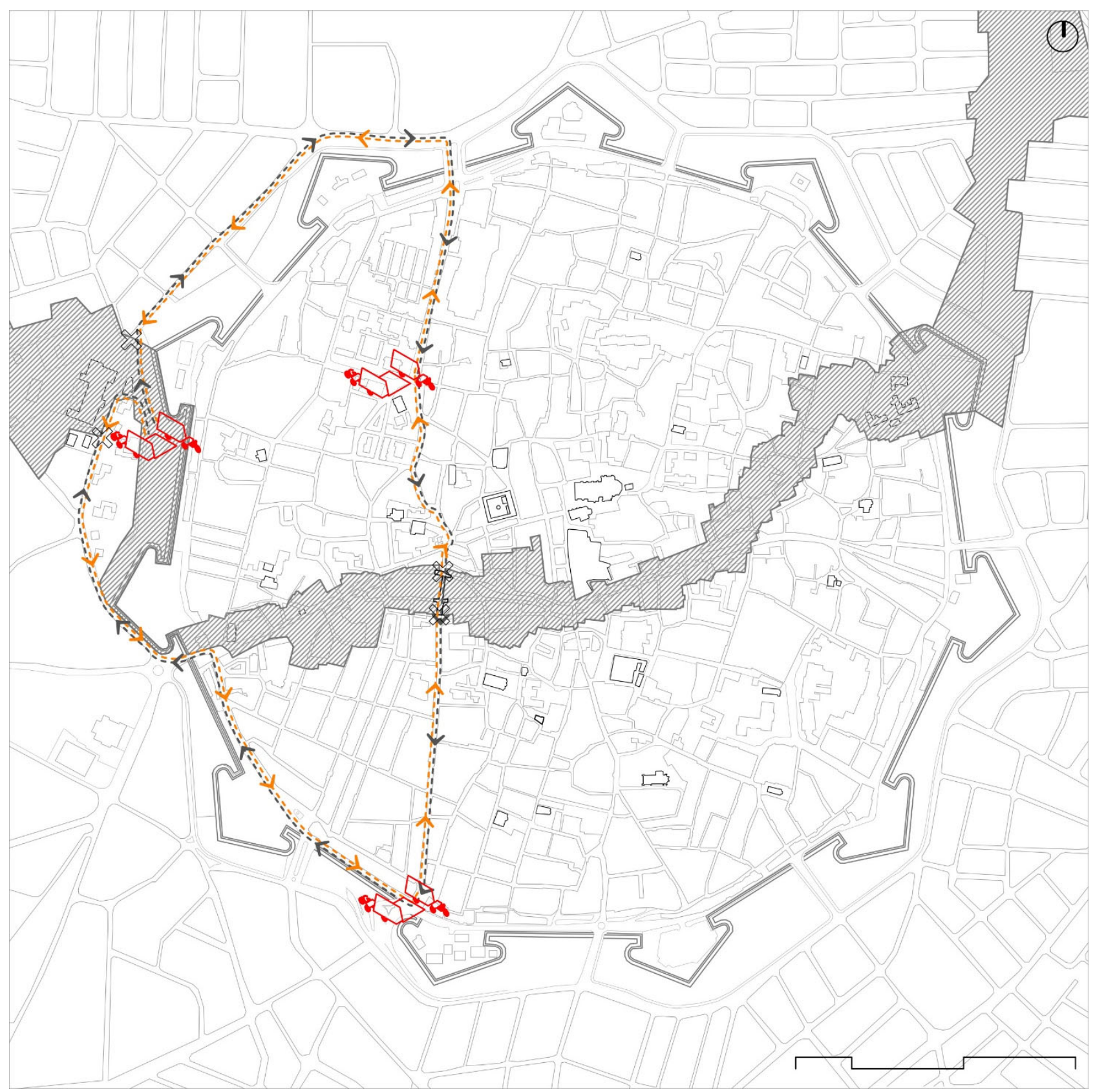

Figure 7. Alice in Meridianland, Nicosia map with the loops of the performance trajectories, 2019. Photo AA\&U.

The Buffer Fringe Performing Arts Festival organizes for the last few years, a weekly event in October. It uses the Home for Cooperation as a touching stone. It is a beautiful meeting place for people coming from the two sides of the divide. It is located by the UN buffer zone, in front of a former hotel, Ledra Palace, actually used for accommodation for the United Nations soldiers. One of the Buffer Fringe Festival's activities is an open-air one-day event that takes place in the moat of the old city walls, part of the UN buffer zone, just behind the Home for Cooperation. For 2019, the organizers invited practices, universities, and NGOs that deal with peacebuilding. They 
invited them to share their work with the visitors by installing a pavilion in the event space. We use our "pavilion plot" as one of the three spaces where the two tricycles with the banners-on-wheels would park.

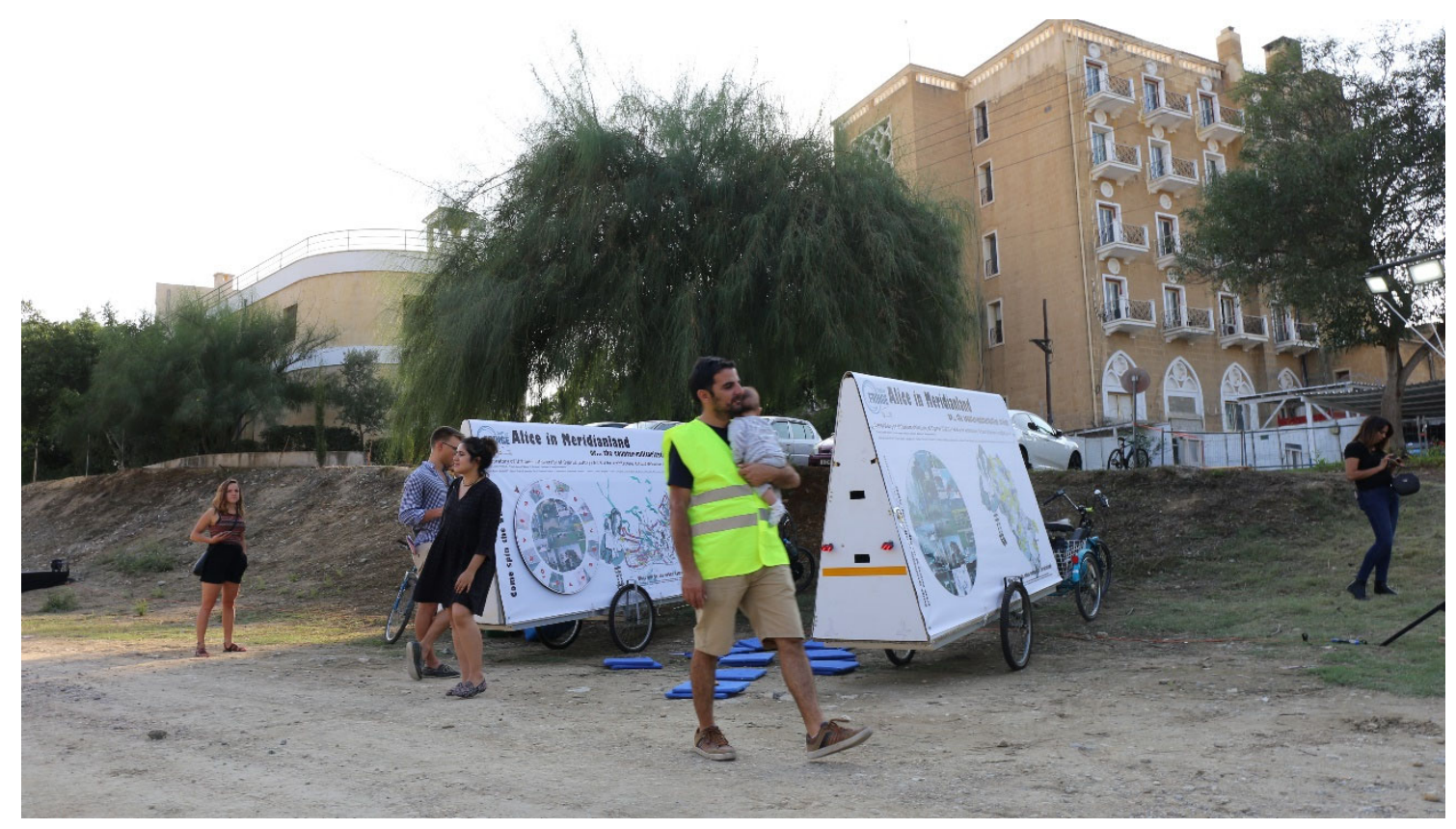

Figure 8. Alice in Meridianland, in the UN buffer zone by Ledra Palace, 2019. Photo AA\&U.

The process of going to these three places as well as departing from them gets a ritual take with a highly symbolic significance. The banners-on-wheels create an in-between event space, a playful interaction for the visitors and passers-by. The first meeting place is at Eleftheria square. Andy and John ${ }^{2}$ are the drivers of the two tricycles. They are followed by many volunteers on foot. Andy is a young volunteer in his late twenties. He comes from Nicosia. During the trip, he confessed to us that in his whole life, he crossed the checkpoint only once when he was a kid, with his parents. He is worrying whether he will find his way in the north part of Nicosia. He has no clue where he is or how to move around. Andy is not an exception. Many young people, part of the majority of the Greek Cypriot population, rarely cross the divide.

The first checkpoints opened in 2003. From 1974 until 2003, it was impossible to cross. In 1974 Turkey invaded the island after a Greek coup d'Etat. The Cypriots were displaced to the south and north parts of the island depending on their ethnicity. 200,000 Greek Cypriots out of 800,000 were displaced to the south. 45,000 Turkish Cypriots out of 100,000 were displaced to the north. The displacement started in 1963 with the bi-communal conflict with Turkish Cypriots confined in ethnic enclaves in the major cities. The UN cease-fire demilitarized zone was established in Nicosia in 1963 and extended along the stretch of the island in 1974. In 1985, the Turkish Cypriots founded the "Turkish Republic of Northern Cyprus". It is a non-recognized country but by Turkey. In 2003, many displaced Cypriots crossed the checkpoints to visit their home left behind in 1974. Since then, a few continue to cross.

\footnotetext{
${ }^{2}$ The names of the participants are altered.
} 
Mental maps are deeply deformed in divided cities. Visitors coming to Nicosia find it very hard to understand how Nicosians get lost during their visits to the "other" part of the city. It takes hardly I 5 minutes to walk the diameter of the perfectly round old city of Nicosia. Yet, it feels fifty years when you finally decide to take the stroll. While riding the tricycle in north Nicosia, Andy is impressed that many people are sitting in cafes along the sidewalks. Streets are empty of people according to his mental map.

Our second meeting place is Ataturk square. The two processions converge after completing the predesignated loop trajectories. Sadly, we left the Syrian boy and his friend, behind. Ataturk square was the ground zero during the British colonial rule. It is the point from where the British measured the distances to the rest of the Cypriot cities. It is the historic central square of the old city deprived however, from the Greek Cypriots inhabitants since the late 1950s.

"It feels like a foreign place for me. Yet, it is utterly familiar due to the British colonial public architecture and its limestone materiality. Thanks to the modernist architecture of the 1940s, the scale, and density of the city, due to the vegetation, I confess to Andy. "It took me 39 years to walk a ten-minute long path", I continue. "I was 39 years old when I visited the north part of the city, an ethnic enclave since 1963. I went to a high school, ten minutes' walk from here", I add while waiting for the second procession to arrive.

In the Ataturk square, there are young Turkish men, most probably soldiers, part of the 40,000 troops of the Turkish army, parked on the island. They are having their Saturday afternoon off. They see me going around shooting pictures of the banners-on-wheels. Three of them ask me if I took their picture. I decline.

We park the tricycles with the banners just next to a large circular bench that marks the center of the square. There is no participation during the forty minutes of our stay. Yet, our method for each of the three spaces is the same: we start playing among us. We are around 10 to 15 people, volunteers that follow the two processions. The passers-by may get curious, but first keep their distance watching us playing and spinning the wheel, and sticking sticky daisies on the banners. Then, they may feel at ease to join us. Yet, the Turkish Cypriot young volunteers enjoy playing ladders \& snakes with the rest of the volunteers, collecting sticky daisies.

John's mental map of the north part of Nicosia is no different than Andy's. The mental maps of the young students and volunteers of the group are equally distorted. Today, they have decided to leave their comfort zone and interact with the "other". It is undeniably, part of the success of the event. A collective leap of faith is taking place. We have put aside our fears, insecurities, and sense of injustice to our ethnic community. We have put aside an attitude of indifference, common to a lot of Cypriots.

The initial structure of the banners-on-wheels was used for the "Urban-a-where?" event back in $2012^{3}$. The banners are made of thick paper structure to be as light as possible.

\footnotetext{
${ }^{3}$ The "Urban-a-where?" project http://www.socratesstratis.com/en/curatorials-list The aim of the "Urban-A-Where?" project (the "U-A-W?" project), is to bring to the surface in a creative and critical manner the processes of making the urban and the need for public engagement. The "UrbanA-Where?" project contributes into the construction of an active urban society. "Get playfully public engaged" is a method that allows to teams of architects, artists and urbanists from Cyprus and other European countries, to assist and criticize everyday processes of making of the urban in Cypriot and other European cities. Curator: S. Stratis
} 
Why Alice is not in Wonderland? Countering the Militarized status quo of Cyprus
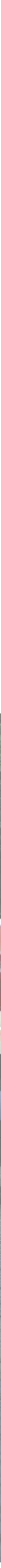

Figures 9 and 10. Alice in Meridianland, at Ataturk square, 2019. Photo AA\&U.

202 | The Journal of Public Space, 5(4), 2020 | ISSN 2206-9658

City Space Architecture / UN-Habitat 

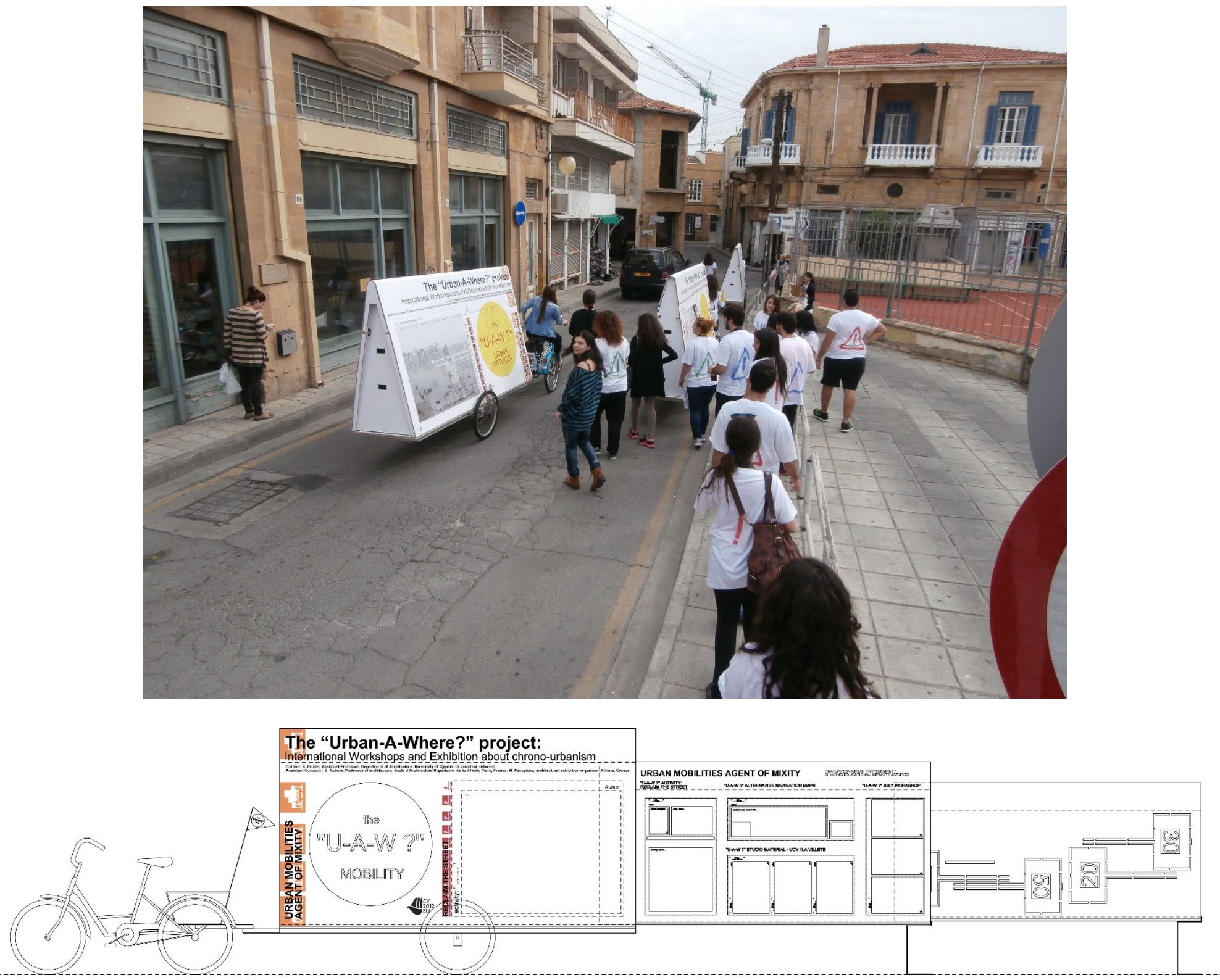

Figures II and I2. The 'Urban-a-where' project 20I2. Photo AA\&U.

Their triangular section gives them their robustness. Additionally, it allows for stowing of our pillows and accessories in the hollow section of the banners. The tricycles run on electricity which makes it much easier to pull the three-meter-long banners along the city's streets.

Our third destination is the Festival's site located on the moat next to Ledra Palace in the UN buffer zone behind the Home for Cooperation, ( $\mathrm{H} 4 \mathrm{C})$. The $\mathrm{H} 4 \mathrm{C}$ is literally and metaphorically space in-between. Thanks to the opening of many check-points, especially that of Ledra Palace in 2003, H4C has become a home for many peacebuilding NGOs. A meeting place for people living in the two parts of the island who cannot cross to the other part, or don't want to. 


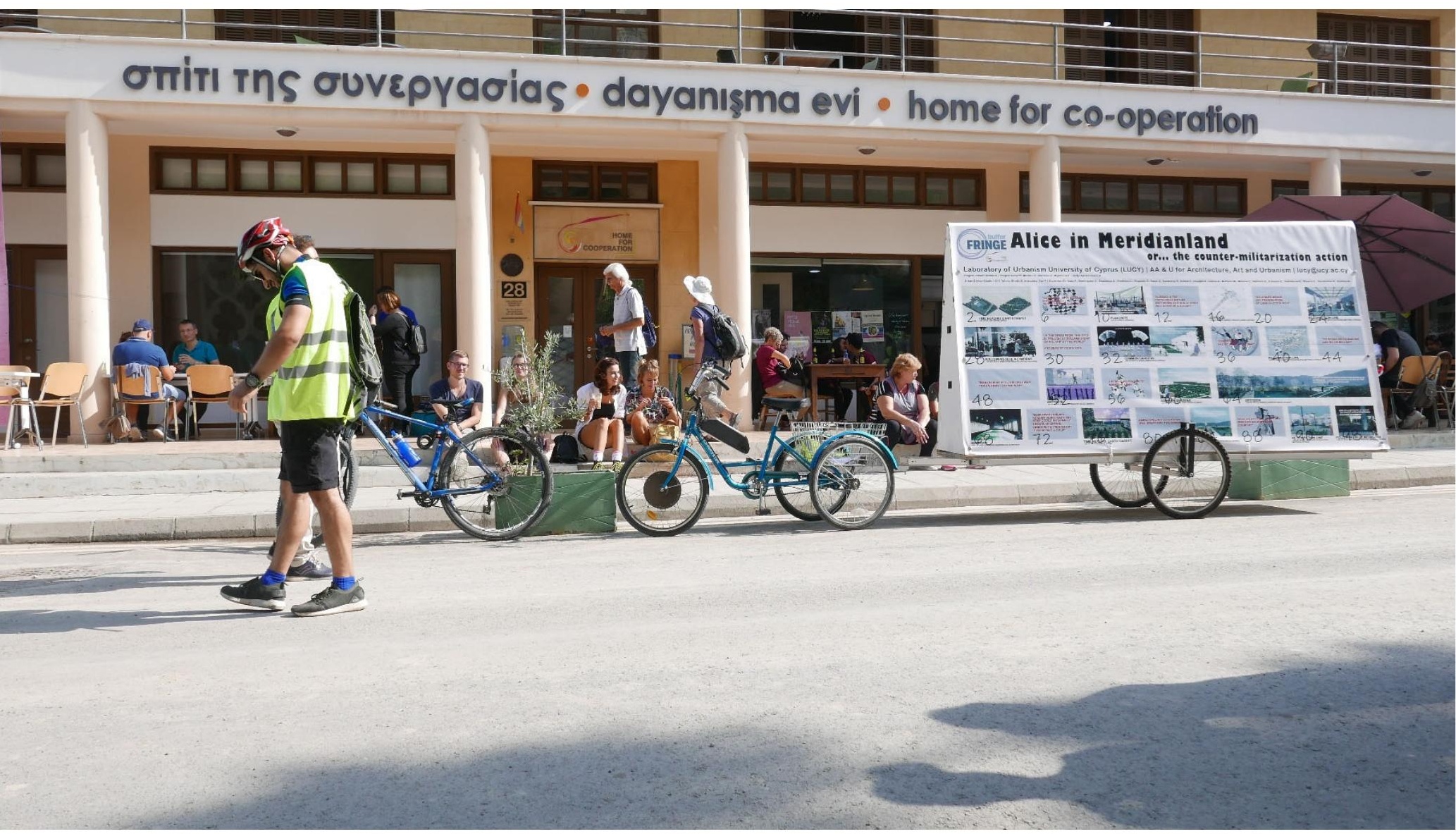

Figure 13. Alice in Meridianland, at Home for Cooperation, 2019. Photo AA\&U.

To my surprise, the pavilions hosting many of the festival's events are military tents handed over by the United Nations forces to the festival's organizers. I am so familiar with such a warlike atmosphere. Yet, I sense a mismatch for hosting a peacebuilding initiative. Our "plot spot" is empty and ready to have our equipment parked and unfolded. We place the banners-on-wheels vertical to the main circulation road, just below a tree. A familiar tree, located on a two-meter higher earth level by the road, running between Home for Cooperation and Ledra Palace. I am bonded to the location of this tree. In 2005, we had our first mobile exhibition, long before the opening of the H4C. The "Call \# 192"4 was the name of our action, part of an international exhibition entitled "Leaps of Faith". Instead of banners-on-wheels placed side by side, we had two buses parked side by side. We had managed to borrow them from the Turkish Cypriot and Greek Cypriot municipalities of the north and south parts of Nicosia.

\footnotetext{
${ }^{4}$ The "Call \#192" project http://www.aaplusu.com/en/projects/the-call-192-project-2005//9 The CALL \# 192 project is a nomad exhibition space defined between two parked municipal buses, borrowed from the two municipalities of Nicosia, exhibiting mental maps of the other part of the city as created by Greek Cypriot and Turkish Cypriot users during a public bus ride.

Project Team: Socrates Stratis, architect, urbanist / Maria Loizidou, visual artist / Charis Pellapaisiotis, photographer.
} 


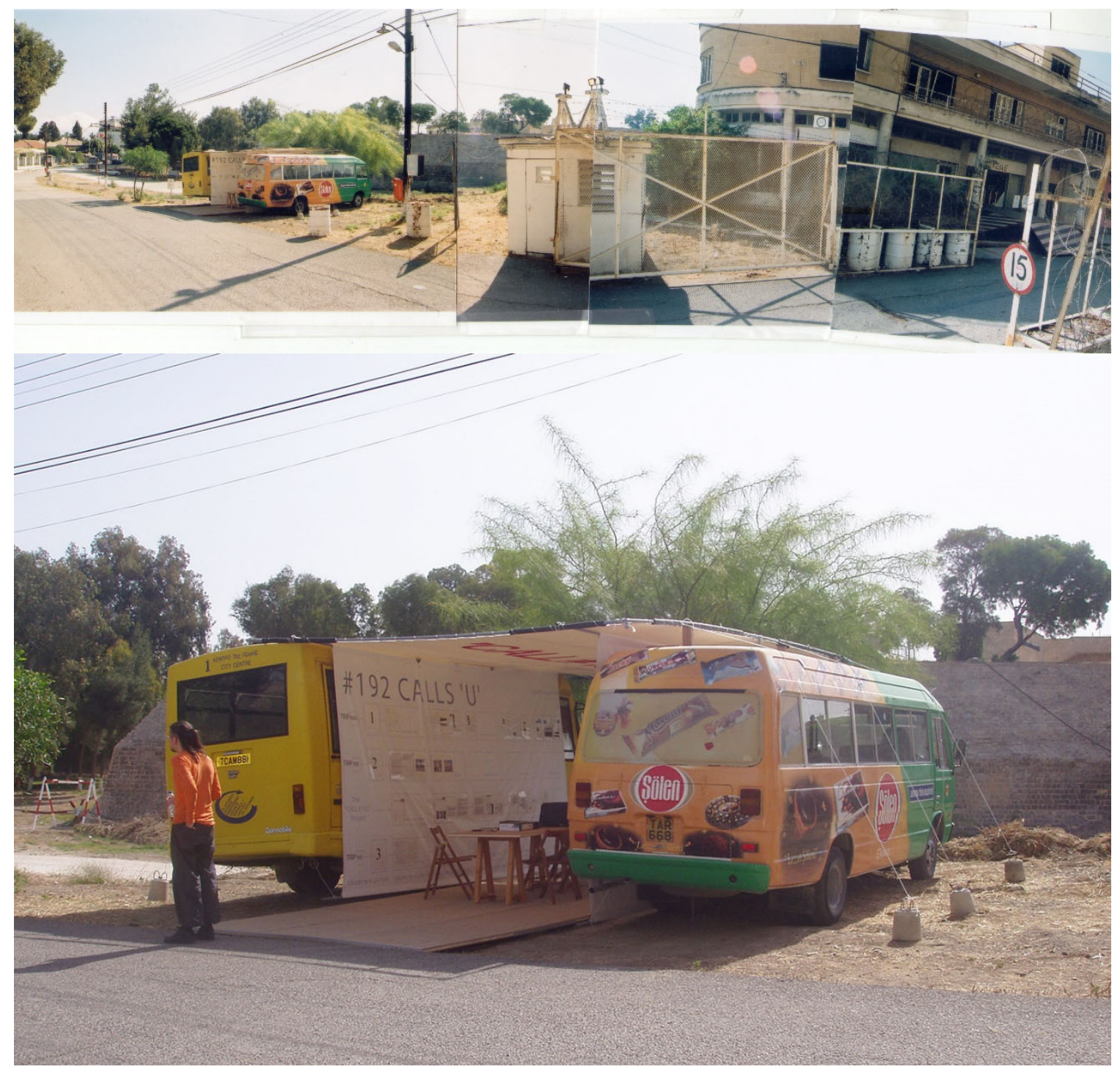

Figures 14 and I5. The 'Call \#192' project, 2005. Photo AA\&U.

Mental maps were the content of that project. Mental maps of Greek Cypriots and Turkish Cypriots while navigating in the other to them, part of the city, by public buses. Mental maps about the unfamiliar. Mental maps are part of the hidden program of Alice in Meridianland action.

The audience of the festival is quite tuned and ready to consume the exhibited works of the one-day event. We get our first impatient visitors before we manage to park both the banners-on-wheels. We have to kindly ask our last visitors for a break since we need to move to our next stop.

We are returning to the same spot after our next stops at Eleftheria and Ataturk squares, completing our loops across the divide. There is a rather big international audience related to the United Nations Forces. There are quite a few Greek Cypriots and Turkish Cypriots who support the reunification of the island. Many of them are young. I am hopeful. There are many families with their young kids, strolling around the pavilions in army tents. Some of them come from Puerto Rico, others from the Netherlands and Cyprus. Yet, looking at the UN soldiers in their formal uniforms, the 
Why Alice is not in Wonderland? Countering the Militarized status quo of Cyprus

military tents, and the foreign audience, I sense for a moment that it is not a Cypriot celebration. One of the United Nations in Cyprus, perhaps.

The audience at Eleftheria square consists mostly of immigrants. They use public spaces as their breakout space from their tiny and overpopulated apartments of the old city. A few Greek Cypriots are passing by. In Ataturk square, the audience keeps itself in a safe distance. The shop-owners, the café users are observing us. "What are you advertising?" is their question to the volunteers. "Peace" is our answer.

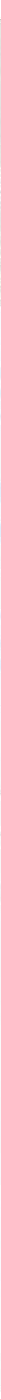

Figure 16. Alice in Meridianland, in the UN buffer zone by Ledra Palace, 2019. Photo AA\&U. 


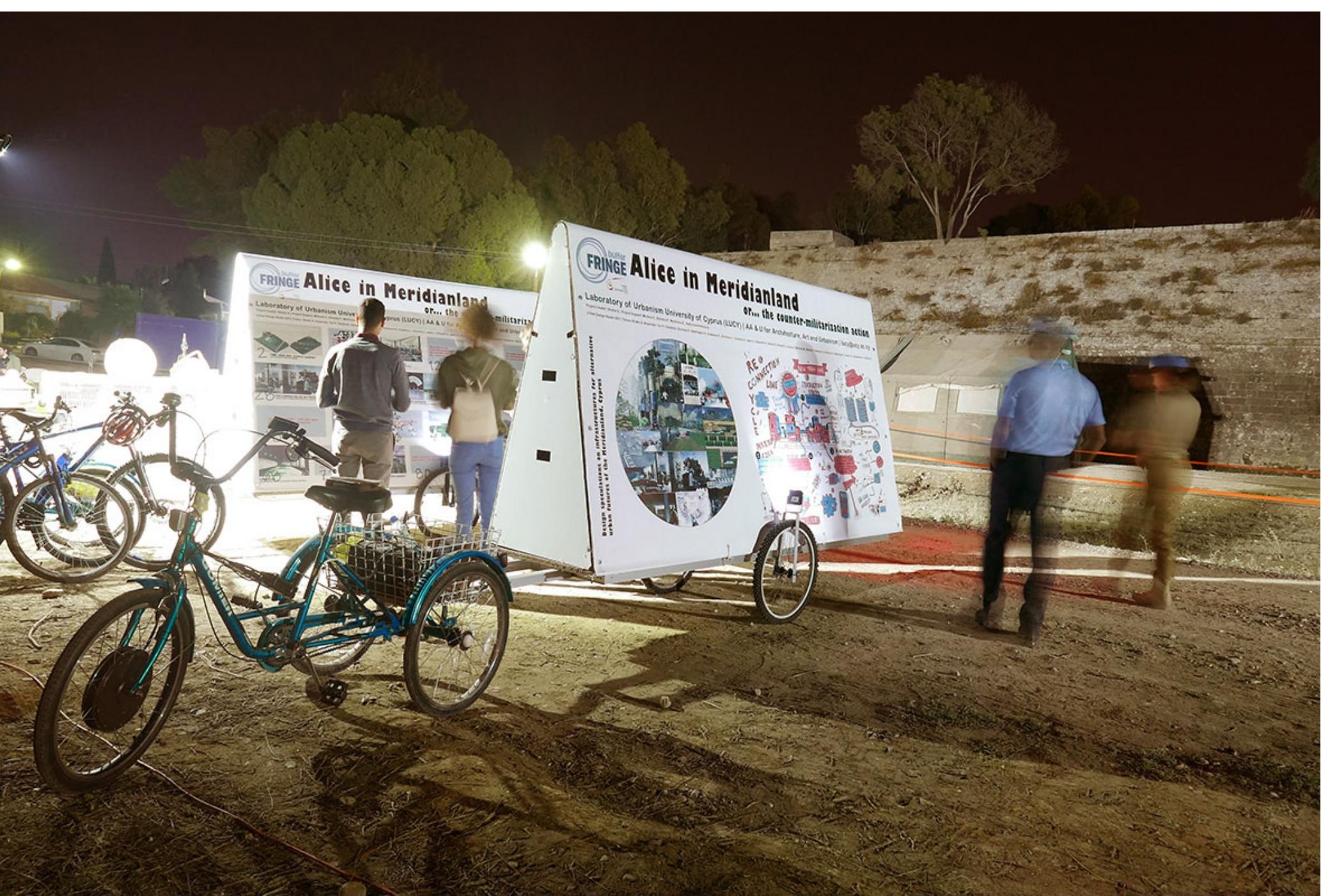

Figure 17. Alice in Meridianland, in the UN buffer zone by Ledra Palace, 2019. Photo AA\&U. 
Why Alice is not in Wonderland? Countering the Militarized status quo of Cyprus

\section{References}

Awan N., Schneider T. and Till J., (eds.) (20II) Spatial Agency and Other Ways of Doing Architecture. New York: Routledge, Oxon

Borden, I., Kerr, J., Pivaro, A. Rendell, J. (eds), (1996), Strangely Familiar: Narratives of Architecture in the City, London: Routledge

Cuff, D. Loukaitou-Sideris A., Presner, T, Zubiaurre M, Jae-an Crisman, J. (2020), Urban Humanities: New Practices for Reimagining the city. Cambridge Massachusetts, London: MIT Press

Demetriou, O. (20I2), Displacement in Cyprus: Consequences of civil and military conflict report I, Nicosia: Peace Research Institute Oslo (PRIO).

Rendell J. (2006) Art and Architecture: A Place Between. London: I. B. Tauris

Rendell, J. (2000), Bazaar Beauties or Pleasure Is Our Pursuit: A Spatial Story of Exchange, in Borden et al. (eds), Unknown City: Contesting Architecture and Social Space, Cambridge, Mass.: The MIT Press, 104-121

Stratis, S. (ed.) (2016), Guide to Common Urban Imaginaries in Contested Spaces, Berlin: jovis. Stratis, S., (2013) Encouraging Co-existences through poly-rhythmic urban environments: the Urban-A-Where project, in Stratis, S. (ed) The UAW BOOK: About Urban Awareness, Seoul: Damdi, 17-39

Stratis, S., (2010) Nicosia Master Plan, Bauwelt Vol. 43.10, 100th year edition "Learning from Europe", Berlin 5I-53

Stratis, S (2006), The CALL \# 192 project, in Uropean Urbanity, edited by Europan Austria and Europan Slovenia, Vienna, New York: Springer. 